\title{
Merchants from the Southern Netherlands (1578-1630)
}

\section{Social and Economic History}

\author{
Oscar Gelderblom \\ Universiteit Utrecht \\ a.j.gelderblom@uu.nl
}

\begin{abstract}
In 1585 the Duke of Parma conquered Antwerp, which was followed by a blockade of the river Scheldt. A large number of merchants moved to Amsterdam. Since the beginning of the twentieth century a historical debate has been going on about the economic effects of these events. The submitted data, gathered from different historical sources, aim to provide a precise answer to this question. Information from nine different sources (e.g. poortersboeken of the city of Amsterdam, two tax registers, Notarieel Archief and voc/WIC-archives) has been combined in an attempt to reconstruct the entire merchant community of Amsterdam between 1578 and 1630. This resulted in a data collection on more than 5,000 wholesale traders. Analysis of the data shows that migration to Amsterdam started long before the siege of Antwerp because of old commercial ties between the two cities. Moreover, the role of the newcomers was of moderate importance. In 1609 the immigrants amounted to one third of Amsterdam's merchant community. The majority of them were young men of modest means, seeking an international career in Amsterdam. Since collaboration between merchants from the north and the south dated back to the 1540s, the influx from Antwerp may be considered part of one single merchant community which developed in the Low Countries in the course of the sixteenth century.
\end{abstract}

\section{Keywords}

social and economic history data - Amsterdam - Southern Netherlands - merchants 
1. Introduction

In 1585, after the Duke of Parma conquered Antwerp, Dutch rebels blocked both the river Scheldt and the Flemish coast. It was the final blow to the commercial hegemony of a city that had been in a state of crisis since the early 1570s. As a result hundreds of merchants flocked to Amsterdam to continue their trade.

Since the beginning of the twentieth century historians have argued either for or against the crucial role of these immigrant entrepreneurs in the rise of Amsterdam as the hub of world trade around 1600 . Those who claim an important role for the immigrants have more or less repeated the ideas that were formulated at the beginning of the twentieth century. In their view, the new merchants were endowed with a capitalist spirit, large amounts of liquid capital, modern trading techniques, extensive commercial networks and a specialisation in specific, often high-value products.

Those who deny a crucial role to the immigrant merchants stress a number of earlier developments that favoured Amsterdam after 1580: the specialisation of Dutch agriculture which made labour from the country side available

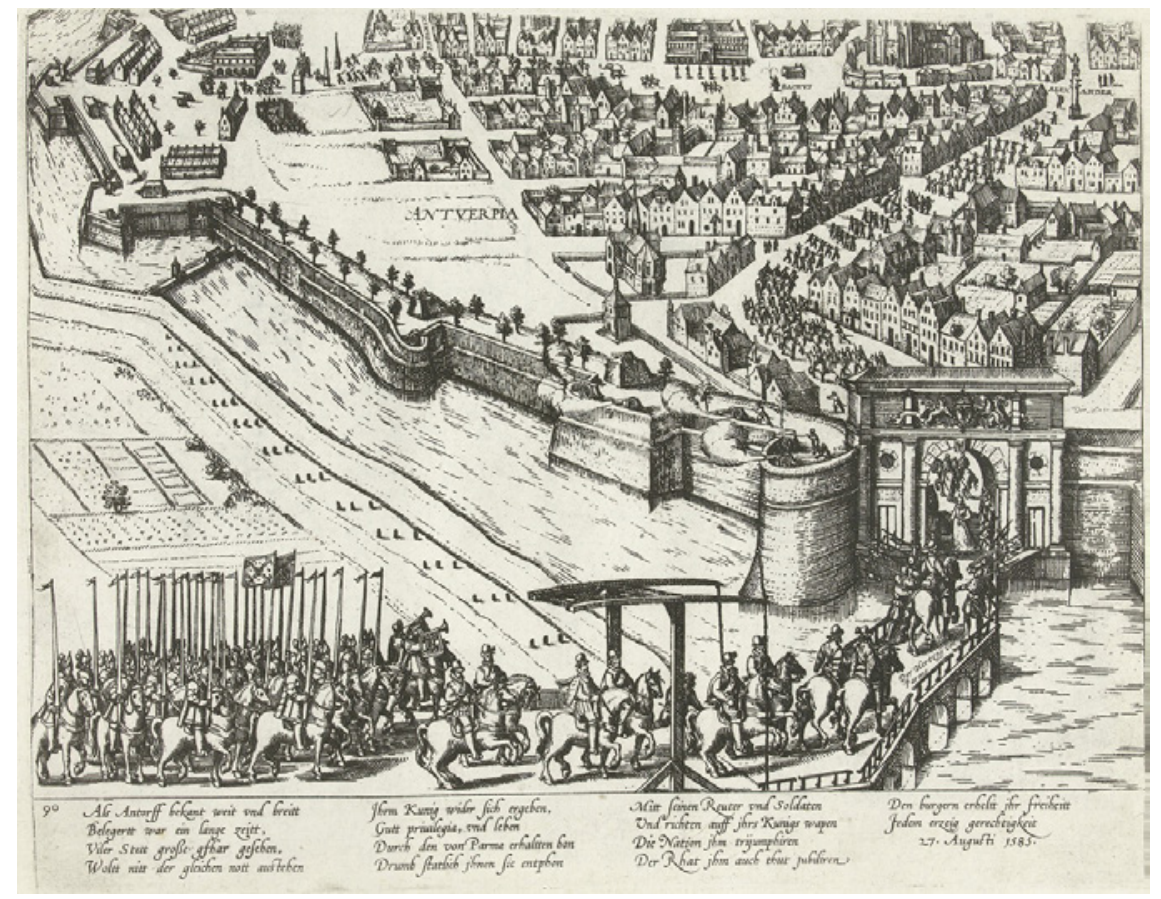

FIGURE 1 Parma entering Antwerp, 1585

SOURCE: HTTP://EN.WIKIPEDIA.ORG/WIKI/FALL_OF_ANTWERP 


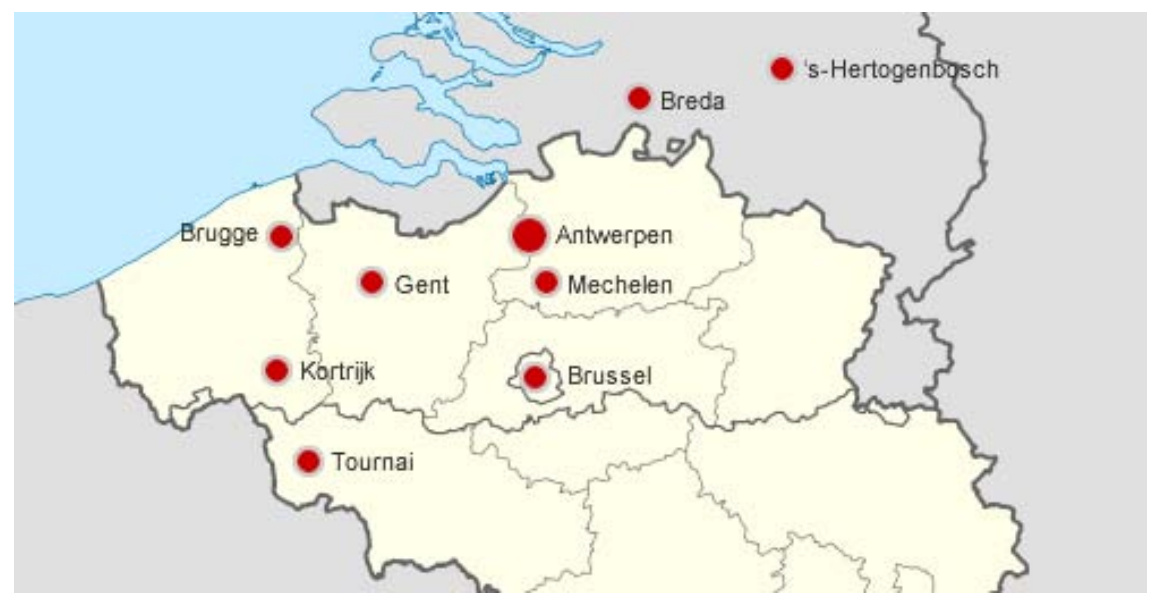

FIGURE 2 Most frequent places of origin as registered in the Burgherbooks.

to the cities, the leading role of the city in the Baltic trade and the large merchant fleet. One could add the excellent geographical position of Amsterdam between northern and southern Europe and the virtual independence of the Dutch Republic from the Habsburg Empire after 1590.

\section{Problem}

The issue of the crucial role of these immigrant entrepreneurs in the rise of Amsterdam has never been settled, primarily because a systematic study of the migration of merchants from the south is lacking. Historians keep referring back to either J.G. van Dillen's analysis of the shareholders of the voc or to biographies of eye-catching entrepreneurs like Isaac Lemaire and Willem Usselincx. This practice has led to the rather flat characterisation of the immigrants as rich, successful, internationally orientated merchants. The present study tries to provide a more accurate account of the contribution of immigrant merchants through a combination of three converging research strategies.

\section{Methods}

Information from nine different sources has been combined in an attempt to reconstruct the entire merchant community of Amsterdam between 1578 
and 1630. This resulted in a collection of names of more than 5,000 wholesale traders. Combining these data with information from secondary sources then allowed the identification of 850 merchants from the southern Netherlands who worked in Amsterdam's wholesale trade between 1578 and 1630.

To analyse the contribution of these immigrants to Amsterdam's commercial expansion a prosopography or collective biography of the entire group of 850 merchants was composed. Key variables in this collective biography were the pattern of immigration, professional status, economic activities, social position, wealth and religious affiliation of the newcomers in Amsterdam. To find out more about the background of the immigrants a second, smaller prosopography was added, analysing the wealth, profession and religion of 150 entrepreneurs from Antwerp in the years before they left for Amsterdam. Even though this prosopographical analysis provides a more complete picture of the newcomers, it does not answer all questions. Group characteristics reveal neither business strategies nor the interaction between newcomers and local merchants. Moreover, the day-to-day reality of wholesale trade remains invisible. To anticipate these obvious shortcomings, an extensive biography of a single merchant family was added. The extensive archives of the Thijs family reveal the story of three generations of merchants who worked either in Antwerp or Amsterdam between $155^{\circ}$ and 1630.

The dissertation (see references) presents the results of this combined research strategy. It sheds new light on the history of the merchants from the southern Netherlands:

1. First of all, it has become clear that migration to Amsterdam started long before the siege of Antwerp. From the 1540s onwards Antwerp merchants regularly visited Amsterdam or even settled there to participate in Baltic trade. Immigration temporarily stopped in the 1570s, when Amsterdam remained loyal to the Spanish king, but after a protestant coup in 1578 the city quickly regained its appeal. By the end of the 1580 s over 200 merchants had decided to continue their business in Amsterdam, rendering it already at an early stage the most important refuge in Europe. But the immigration did not halt there.

2. In 1609 no less than 450 entrepreneurs from the south worked in the Amsterdam's wholesale trade. Despite this impressive figure, however, the immigrants only amounted to one third of Amsterdam's merchant community; they were outnumbered by local traders and newcomers from the northern provinces.

3. After 1610 the first generation of immigrants was replaced by a second generation. Twenty years later the immigrant merchant community still numbered at least 350 . 


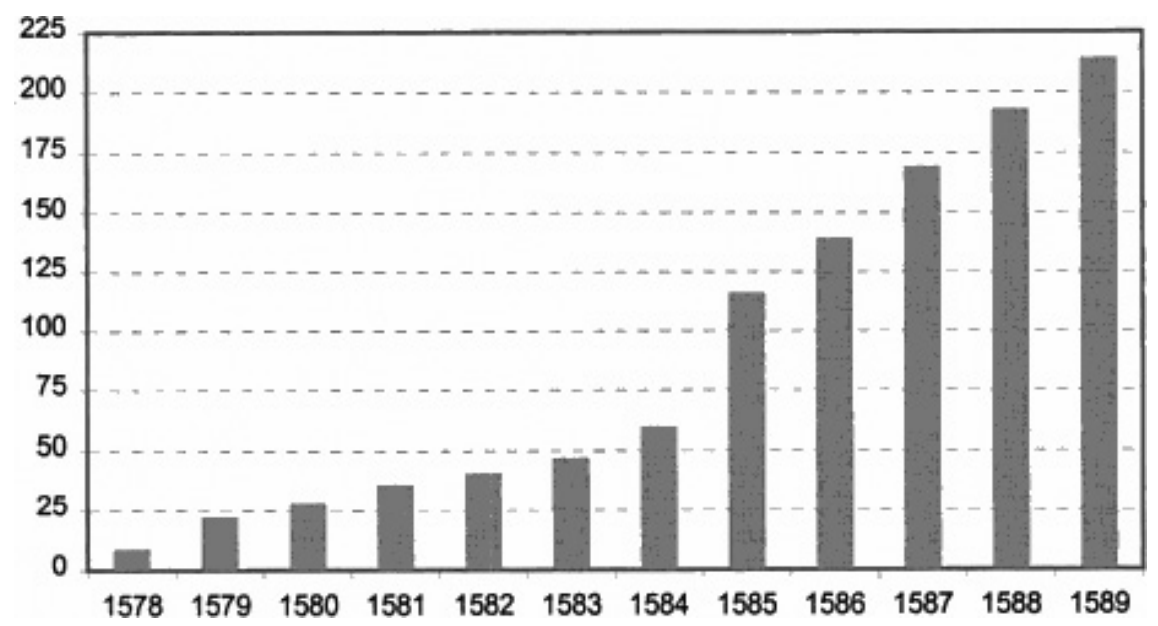

FIGURE 3 Immigration of merchants from the Southern Netherlands in Amsterdam, 1578-1589 (cumulative).

GELDERBLOM, 2000.

\section{Data}

- Data deposited at DANS: DoI:10.17026/dans-zcd-mebh

- Temporal coverage: $155^{0-1631}$

Historical sources, like the Poortersboeken Amsterdam, two tax registers, Notarieel Archief and voc/WIC-archives have been used in order to create a dataset on 16th and $17^{\text {th }}$ century Amsterdam merchants. Selection and clustering resulted in a subset of merchants originating from the Southern Low Countries. To these three more database-tables, offering information on the social-religious context of the individual merchants, have been added: files Fo3, Fo4 and F1o. A full description of the sources is to be found in the DANS Data Archive. Synthesis of the data in the key-database Prosopography Amsterdam (Fo6) - preview available online.

Data-gathering and selection procedures have been explicitated in Gelderblom's thesis Zuid-Nederlandse kooplieden en de opkomst van de Amsterdamse stapelmarkt (1578-1630), Hilversum 2000.

\section{Conclusions}

Systematic analysis of their background shows that most of these entrepreneurs were at the very start of a career in international trade. It is true that Antwerp counted many wealthy men in the 1570 s and 1580 , but they were of 


\begin{tabular}{|c|c|c|c|c|c|}
\hline$A$ & E & c. & D & E & $F$ \\
\hline ID & Persid & Family name & First name & Profession & Origin \\
\hline 1 & 201 & Adriaensz & Aert & Lakenkoper & Sertagenbouch \\
\hline 2 & 203 & Adriaensz & willem & Zeepzieder & t'sartoghenbos \\
\hline 3 & 5702 & Barnart52 & Jan & Kramer & Duffle \\
\hline 4 & 402 & Claesz & Anthemy & Kocpman van koperwerk & Antwerpen \\
\hline 5 & 501 & Cornelisz & Jan & Viskoper & Antwerpen \\
\hline 6 & 601 & Cristiaensz & Roelandt & Kocpman & Brugge \\
\hline 7 & 801 & Everts & Martijntgen & Linnenlakenkoopster & Antwerpen \\
\hline 8 & 1001 & Florisz & Abraham & Kruidenier & Antwerpen \\
\hline 9 & 1201 & Gerritsz & Philips & Zecpzicder & "s Hertogenbassche \\
\hline 10 & 47901 & Gillis & Henrikk & Kocpman & Brugge \\
\hline 11 & 26502 & Martensz & Matheeus & Kruidenier & Antwerpen \\
\hline 12 & 39203 & Michiels & Lijsteth & & \\
\hline 13 & 29901 & Otten & Earnart & Koopman & Antwerpen \\
\hline 14 & 49701 & Willemsz & Jasper & Kocpman & Antwerpen \\
\hline 15 & 3702 & Woutersz & Harman & Kramer & "s-Hertogenbosch \\
\hline 16 & 3701 & Woutersz & Adfiaen & & \\
\hline 17 & 3501 & Wijnantsz & Wijnant & Kramer & "s Hertozenbasch \\
\hline 18 & 51002 & Auxbrebis & Bartholomeas & Kocpman & Amsterdam \\
\hline 19 & 4101 & Baerle & Davit van & & Amsterdam \\
\hline 20 & 5701 & Barnard & Jacques & & \\
\hline
\end{tabular}

FIGURE 4 Example: data from the burgherbooks (poortersboeken), Amsterdam 1531-1655.

(View interactive spreadsheet here.)

HTTPS://EASY.DANS.KNAW.NL/UI/DATASETS/ID/EASY-DATASET:43065/TAB/1

\section{Most frequent professions}

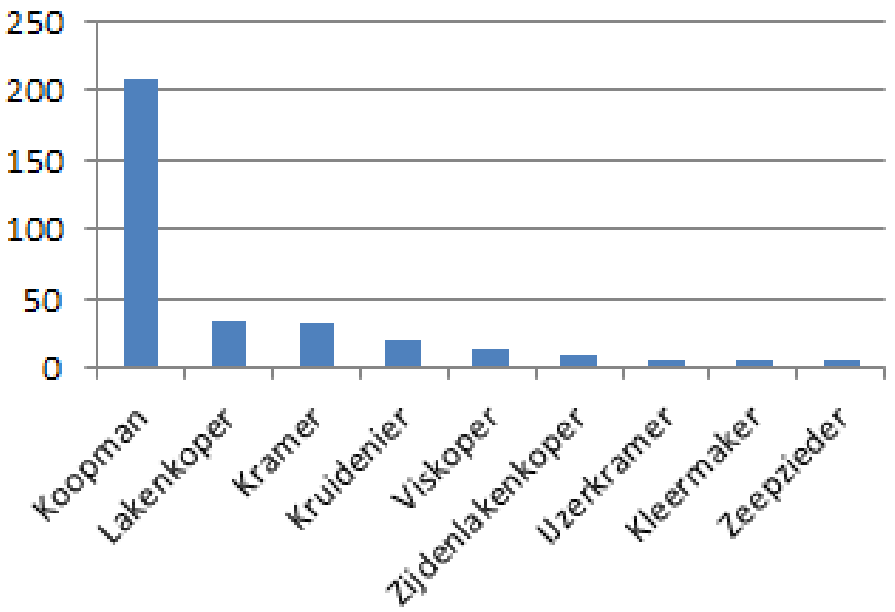

Profession

FIGURE 5 Most frequent professions mentioned in the burgherbooks. (View interactive spreadsheet here.)

HTTPS://DOCS.GOOGLE.COM/SPREADSHEETS/D/1GRUKLOC6ROMDMYVCKN1Y SICUSBY5BR7WWLRBMHXX9XC/EDIT?USP=SHARING 


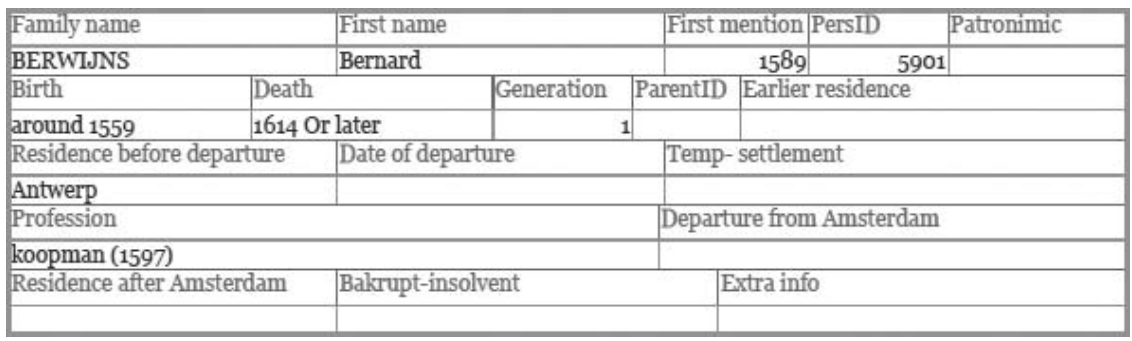

FIGURE 6 Prosopography of about 850 merchants. (Download pdf (3 Mb) or view interactive spreadheet.)

no great importance for Amsterdam. Many leading merchants from Germany, England, France, Spain and Italy simply returned to their home countries. Most native elite merchants stayed behind or moved to other European cities; only a few dozen settled in Amsterdam. The bulk of the immigrants were young men of modest means. They were born and raised in the southern Netherlands and still at the beginning of their career in international trade. Some had not even started as wholesalers, witness the migration of pedlars and artisans. What's more, one third of the entrepreneurs who settled in Amsterdam had never lived in Antwerp. They moved directly from towns in Flanders, Brabant, Artois and Hainault.

For almost all of them the breakthrough in international trade came after they left the southern Netherlands. Once in Amsterdam they started buying and selling new products, discovering new markets, and constructing international networks. Even elite merchants like Jan Jans Carel, Pieter Lingtens, Isaac Lemaire and the Van Os brothers, started their splendid careers in the 1580 in Amsterdam - not in Antwerp. The most striking feature of their enterprises was combination of rich trades and bulk trades. It is true that the immigrants were strong in rich trades, like textiles, dyestuffs, spices and industrial products, but they also engaged in bulk trades. Foodstuffs, wood, hides, metal and various Baltic products made up for one third of all their transactions. The immigrants were strong in the Mediterranean and Russia, but also participated in the traditional Dutch trade between the Baltic and the Atlantic coast of France and Portugal. The economic activities of merchants from the northern Netherlands show a similar vein. They too had their proper specialization - the trade in foodstuffs and bulk products from the Baltic - but that did not keep them from buying and selling textiles, dyestuffs, sugar and spices. Moreover, with the notable exception of Russia before 1609 , native Dutch merchants were present in every market in Europe and the rest of the world. 


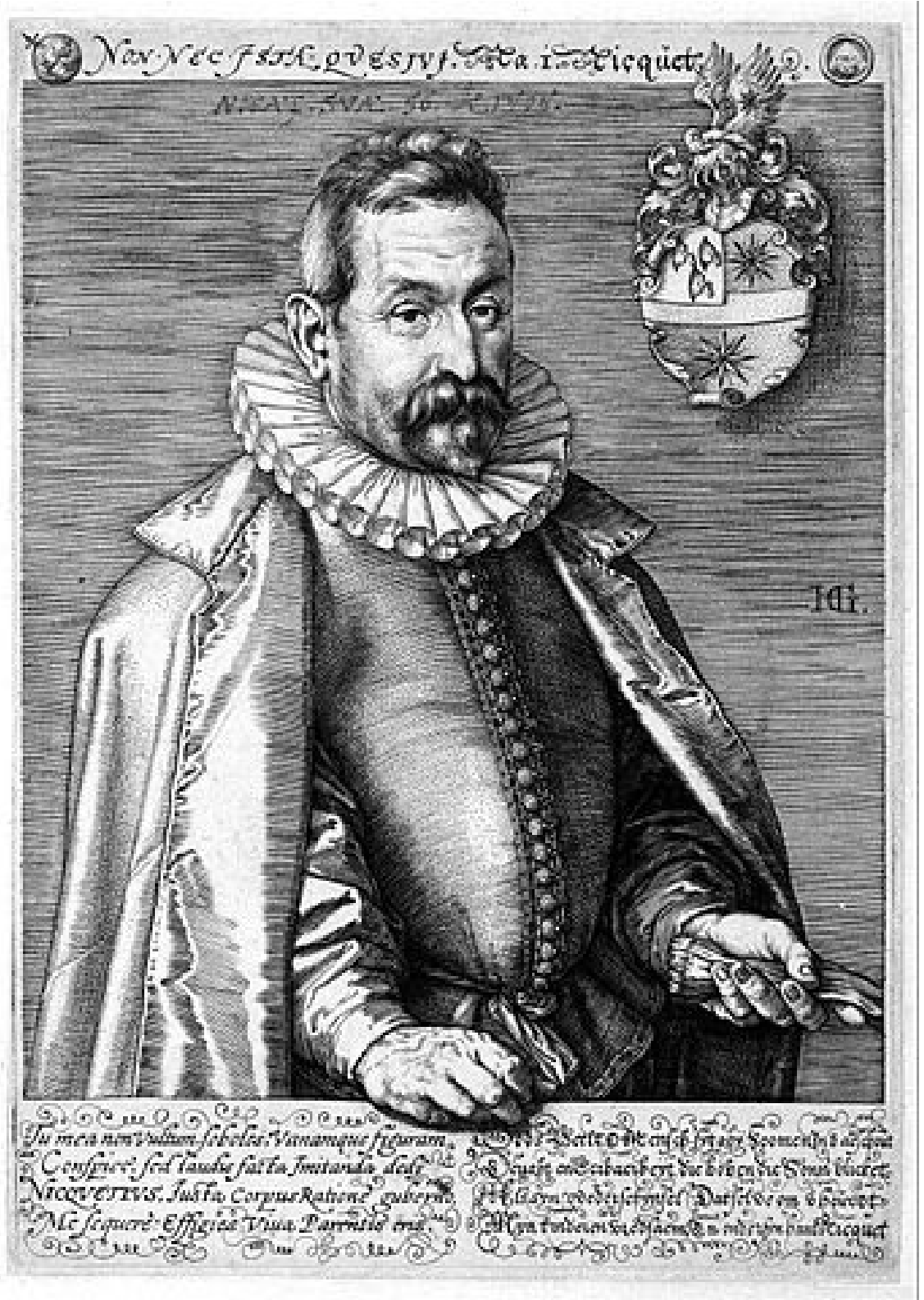

FIGURE 7 Jan Nicquet (1539-1608) was already a wealthy merchant in Antwerp. He turned out to Hamburg in 1585, but moved shortly after 1590 in Amsterdam, where he did good business until his death. 
As far as the organisation of trade is concerned, differences between the two groups were more pronounced. Well into the seventeenth century merchants from both the northern and southern Netherlands preferred to work in companies with family members. If 'mixed' partnerships did occur, business associates were related by marriage as a rule. The same preferences applied in the choice of foreign agents. Merchants strongly favoured commissions to relatives and friends abroad. If this was not possible, occasionally, they tried to get in touch with agents that were recommended by family members or friends. These clear preferences notwithstanding, merchants from the south and the north did co-operate regularly. They bought each others' products, concluded freight contracts together, and joined forces in their attempts to conquer the world outside Europe. The case-study of Hans Thijs even suggests that immigrants borrowed money from local merchants to finance their trade.

There are two explanations for the observed co-operation between merchants from the north and the south, and their combination of bulk trades and rich trades:

1. The first explanation goes back to the division of labour that developed between entrepreneurs in Antwerp and Amsterdam after 1540. Textiles and industrial products from the southern Netherlands were exported in Dutch ships. Antwerp merchants settled in Amsterdam to participate in the city's Baltic trade. Dutch merchants travelled to Antwerp to sell leather, grain, dairy products, fish and other foodstuffs. As a result merchants from the south were familiar with the Dutch merchant fleet, the wholesalers of Amsterdam, and the goods they traded long before difficulties arose in Antwerp. Add to this the displacement of the southern export-oriented industry to Holland and it comes as no surprise that after 1578 so many merchants moved directly to Amsterdam. It was the easiest way to restore the complementarity of bulk trades and rich trades, or to continue the build-up of commercial enterprise.

2. But there was more to the success of immigrant merchants than the old ties between the two cities alone. In the long run, entrepreneurs who wanted to build a career in international trade, took advantage of the easy access to the Amsterdam staplemarkt. With the notable exception of the Russia trade - which was dominated until 1609 by a small group of immigrants from Antwerp - all markets and products were readily accessible to everybody in Amsterdam. Religion, nationality, or wealth never obstructed participation in the city's international trade. Nonetheless one might expect that individual merchants, after having reached a certain position, would try to protect their trading interests by fencing 
off their products and markets from new competitors. Indeed, attempts were made to establish cartels or monopolize trade with government support. Both the city council and the States-General, however, refused to grant monopolies, unless the interests of all merchants were threatened by foreign competitors, corsairs, or pirates. It is also true that Amsterdam's wholesale trade became more and more regulated after 1609, but the measures taken by the local government were only designed to secure accessibility to the Amsterdam market. The best proof for the lasting openness of the staple market is the sustained immigration of merchants, mostly from the northern Netherlands, well into the seventeenth century.

All this puts the immigration from the southern Netherlands in a new perspective. No other city in Europe welcomed as many merchants from the southern Netherlands as Amsterdam after 1578. In contrast with prevailing ideas, however, these immigrants were far from a merchant elite at the time of their arrival. The vast majority consisted of entrepreneurs on the threshold of their career in international wholesale trade. In this respect there is a striking similarity to merchants originating from the northern Netherlands. Even though their economic background differed, both groups benefited from Amsterdam's excellent opportunities to expand their trade, enter new markets, sell new products, and build commercial networks spanning the whole of Europe. Since collaboration between merchants from the north and the south dated back to the 1540 s, they may be considered part of one single, native merchant community which developed in the Low Countries in the course of the sixteenth century. The availability of such a large reservoir of entrepreneurship was one of the structural factors that enabled Amsterdam to dominate world trade.

\section{Reference}

Gelderblom, O. (2000). Zuid-Nederlandse kooplieden en de opkomst van de Amsterdamse stapelmarkt (1578-1630), Hilversum. 